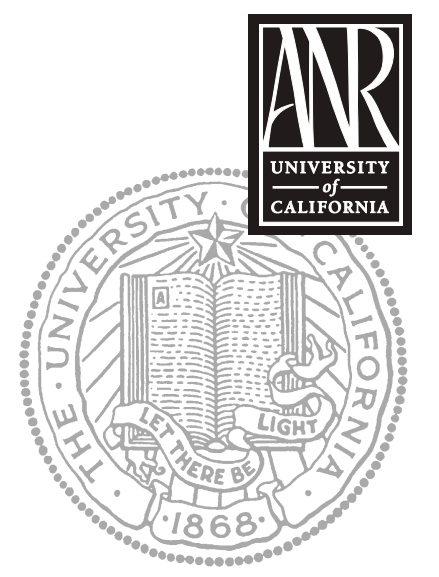

UNIVERSITY OF CALIFORNIA

Division of Agriculture and Natural Resources http://anrcatalog.ucdavis.edu

\title{
Hatching Egg Sanitation: The Key Step in Successful Storage and Production
}

RALPH A. ERNST, University of California Cooperative Extension Poultry Specialist, University of California, Davis

\section{PRODUCING CLEAN EGGS}

Sanitation is essential in successful hatching egg production, and the most important step in egg sanitation is producing nest-clean eggs. This requires a carefully planned management system. The following practices have proven to be useful in producing clean eggs for hatching and in keeping the eggs clean until they are set in incubators.

- Maintain birds on wire, plastic, or wooden slatted floors whenever possible. However, some commercial strains of chickens and turkeys do not produce well in this environment and must have litter floors in part or all of the house.

- To keep floor eggs (eggs laid on the floor) to a minimum, provide 1 nest for every 4 hens. Be sure nests are in place before egg production starts.

- Keep nests filled with clean nesting material such as wood shavings, rice hulls, or nest pads.

- Collect eggs frequently (at least 4 times a day).

- Exclude hens from nests at night. This prevents hens from becoming broody (attempting to incubate eggs and remain on the nest) and keeps nests cleaner.

- Maintain dry litter at all times.

- Collect eggs on clean, sanitized plastic flats or in clean egg baskets.

- Separate cracked, stained, heavy, or dirty eggs as you collect them, and don't incubate them.

- Sanitize clean eggs as soon as possible after collection. Sanitation kills microbes on the outside of the shell. It does not kill all of the microbes that have penetrated the shell.

- Always wash hands thoroughly with a disinfectant soap before handling eggs.

- Cool eggs overnight in flats before placing them in cases. If eggs are to be stored, place them in a clean room held at $55^{\circ}$ to $68^{\circ} \mathrm{F}\left(12.8^{\circ}\right.$ to $\left.20.0^{\circ} \mathrm{C}\right)$ and 75 percent relative humidity (see table 1 ).

- Prevent eggs from sweating (forming surface moisture from condensation) when they are moved from cold storage into a warmer room. You can prevent sweating by putting eggs in trays in a temperature-controlled room (see table 2 ).

Table 1. Recommended hatching egg storage temperatures.

\begin{tabular}{|c|c|c|}
\hline & \multicolumn{3}{|c|}{ Recommended storage temperature } \\
\hline Duration of egg storage (days) & ${ }^{\circ} \mathrm{F}$ & ${ }^{\circ} \mathrm{C}$ \\
\hline 1 & 68 & 20.0 \\
\hline $1-4$ & 65 & 18.3 \\
\hline 5 or more* & $55-60$ & $12.8-15.6$ \\
\hline
\end{tabular}

Note: *Eggs stored more than 7 days benefit from daily turning and storage in plastic bags. 
Table 2. Temperature and relative humidity in egg-handling rooms that cause eggs to sweat when stored at $60^{\circ}$ or $65^{\circ} \mathrm{F}\left(15.6^{\circ}\right.$ or $\left.18.3^{\circ} \mathrm{C}\right)$.

\begin{tabular}{|c|c|c|c|}
\hline $\begin{array}{c}\text { Temperature of room in which } \\
\text { eggs are handled }\end{array}$ & \multicolumn{2}{|c|}{$\begin{array}{c}\text { Relative humidity }(\%) \text { at which } \\
\text { eggs begin to sweat }\end{array}$} \\
\hline$\left({ }^{\circ} \mathrm{F}\right)$ & $\left({ }^{\circ} \mathrm{C}\right)$ & $\begin{array}{c}\text { Eggs removed from } 60^{\circ} \mathrm{F} \\
\left(15.6^{\circ} \mathrm{C}\right) \text { storage }\end{array}$ & $\begin{array}{c}\text { Eggs removed from } 65^{\circ} \mathrm{F} \\
\left(18.3^{\circ} \mathrm{C}\right) \text { storage }\end{array}$ \\
\hline 60 & 15.6 & $\mathrm{NA}$ & $\mathrm{NA}$ \\
\hline 65 & 18.3 & 85 & $\mathrm{NA}$ \\
\hline 70 & 21.1 & 71 & 83 \\
\hline 75 & 23.9 & 60 & 71 \\
\hline 80 & 26.7 & 51 & 60 \\
\hline 85 & 29.4 & 44 & 51 \\
\hline 90 & 32.2 & 37 & 43 \\
\hline 100 & 37.8 & 28 & 32 \\
\hline
\end{tabular}

Key: NA = Eggs do not sweat under these conditions.

\section{EGG SANITATION}

Several methods are available for sanitizing hatching eggs. The best choice for a particular farm will depend on factors such as the size of the operation, potential use of the chicks, the history of disease problems at the site, as well as the costs of alternative equipment and chemicals. Small farms may find that the best alternative is to store hatching eggs in a clean environment and incubate them as soon as possible without sanitation. Large commercial producers should consult a poultry veterinarian or UC Cooperative Extension poultry specialist for advice on the best egg-handling and sanitation program for their needs.

\section{Fumigation}

Formaldehyde gas fumigation has long been used to reduce contamination on eggs. Label registration for this use was withdrawn for a time due to its potential human toxicity, but the U.S. EPA has again registered several formaldehyde products for incubator and hatching egg fumigation. However, at this time no formaldehyde product is registered in California for this use.

\section{Spray Application}

Solutions containing disinfectants can be sprayed onto clean eggs during collection. Any disinfectant registered for use on hatching eggs can be used. See "Disinfectants for Egg Sanitation," below.

\section{UV Light}

Eggs can be sanitized by exposure to ultraviolet light. Commercial sanitizing equipment using UV light is available for commercial producers.

\section{Egg Washing}

Some producers prefer to wash hatching eggs. Egg washing effectively sanitizes hatching eggs if proper equipment is available to do the job correctly. However, washing can contaminate the eggs if the water temperature drops below recommended levels or if contamination exceeds the capacity of the disinfectant (a particular concern in reservoir-type, or immersion, washers). Wash water must always be hotter than the eggs: the recommended range is $110^{\circ}$ to $120^{\circ} \mathrm{F}\left(43.3^{\circ}\right.$ to $\left.48.9^{\circ} \mathrm{C}\right)$. The washing solution must contain an appropriate sanitizer. It is best to use a washer that does not recirculate water. 
If an immersion washer is used, the water must be changed frequently; do not wash more than 200 eggs per gallon of solution capacity before changing the washing solution. Immersion time should not exceed 3 minutes and eggs should be thoroughly dry before they are put into cases. To be most effective, reservoir-type washers should be equipped with systems to monitor and control sanitizer levels. This type of washer should have a final sanitizing rinse with a solution that is not recirculated. Several commercial egg washing machines are available that effectively sanitize hatching eggs when used properly. Only good-quality water with less than $2 \mathrm{ppm}$ iron should be used for egg washing.

\section{DISINFECTANTS FOR EGG SANITATION}

Several commercial products are registered for hatching egg sanitation. You can find an extensive list of disinfectants at the National Biosecurity Resource Center for Animal Health Emergencies Web site at http://www.biosecuritycenter.org/disinfect.htm. Chlorine-based disinfectants containing a cleaning agent are widely used to wash table eggs and have proven to be safe for hatching egg sanitation. Several commercial disinfectant formulas are registered for hatching egg washing. University of California research has shown that quaternary ammonium is an excellent sanitizer for hatching eggs. The advantages of quaternary ammonium are that it

- is safe for hatching eggs

- leaves residual protection on eggs

- is safe for equipment and personnel

- is reasonable in cost

\section{FOR MORE INFORMATION}

You'll find more information on poultry in the following ANR Communication Services products:

Hatching Egg Breakout, Video V-86W, 1986.

National 4-H Avian Bowl Manual packet, Publication 4-H 2069.

Visit our online catalog at http://anrcatalog.ucdavis.edu. You can also place orders by mail, phone, or fax, or request a printed catalog of publications, slide sets, and videos from

University of California

Agriculture and Natural Resources

Communication Services

6701 San Pablo Avenue, 2nd Floor

Oakland, California 94608-1239

Telephone: (800) 994-8849 or (510) 642-2431; FAX: (510) 643-5470

E-mail inquiries: danrcs@ucdavis.edu

An electronic version of this publication is available on the ANR Communication Services Web site at http://anrcatalog.ucdavis.edu.

\section{Publication 8120}

(C) 2004 by the Regents of the University of California, Division of Agriculture and Natural Resources. All rights reserved. 
The University of California prohibits discrimination against or harassment of any person employed by or seeking employment with the University on the basis of race, color, national origin, religion, sex, physical or mental disability, medical condition (cancer-related or genetic characteristics), ancestry, marital status, age, sexual orientation, citizenship, or status as a covered veteran (special disabled veteran, Vietnam-era veteran or any other veteran who served on active duty during a war or in a campaign or expedition for which a campaign badge has been authorized). University Policy is intended to be consistent with the provisions of applicable State and Federal laws.

Inquiries regarding the University's nondiscrimination policies may be directed to the Affirmative Action/Staff Personnel Services Director, University of California, Agriculture and Natural Resources, 300 Lakeside Drive, 6th Floor, Oakland, CA 94612-3550 (510) 987-0096. For a free catalog of other publications, call (800) 994-8849. For help downloading this publication, call (530) 754-5112.

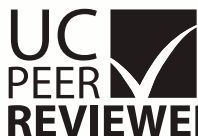

pr-01/04-SB/CR

This publication has been anonymously peer reviewed for technical accuracy by University of California scientists and other qualified professionals. This review process was managed by the ANR Associate Editor for Animal, Avian, Aquaculture, and Veterinary Sciences. 